\title{
Data-driven mapping of the potential mountain permafrost distribution
}

\author{
Nicola Deluigi (nicola.deluigi@unil.ch) ${ }^{\mathrm{a}}$, Christophe Lambiel ${ }^{\mathrm{a}}$, Mikhail Kanevskia \\ ${ }^{a}$ Institute of Earth Surface Dynamics, University of Lausanne, Lausanne, Switzerland
}

\begin{abstract}
Existing mountain permafrost distribution models generally offer a good overview of the potential extent of this phenomenon at a regional scale. They are however not always able to reproduce the high spatial discontinuity of permafrost at the micro scale (scale of a specific landform; ten to several hundreds of meters). To overcome this lack, we tested an alternative modelling approach using three classification algorithms belonging to statistics and machine learning: Logistic regression, Support Vector Machines and Random forests. These supervised learning techniques infer a classification function from labelled training data (pixels of permafrost absence and presence) with the aim of predicting the permafrost occurrence where it is unknown. The research was carried out in a $588 \mathrm{~km}^{2}$ area of the Western Swiss Alps. Permafrost evidences were mapped from ortho-image interpretation (rock glacier inventorying) and field data (mainly geoelectrical and thermal data). The relationship between selected permafrost evidences and permafrost controlling factors was computed with the mentioned techniques. Classification performances, assessed with AUROC, range between 0.81 for Logistic regression, 0.85 with Support Vector Machines and 0.88 with Random forests. The adopted machine learning algorithms have demonstrated to be efficient for permafrost distribution modelling thanks to consistent results compared to the field reality. The high resolution of the input dataset (10 meters) allows elaborating maps at the micro scale with a modelled permafrost spatial distribution less optimistic than classic spatial models. Moreover, the probability output of adopted algorithms offers a more precise overview of the potential distribution of mountain permafrost than proposing simple indexes of the permafrost favorability. These encouraging results also open the way to new possibilities of permafrost data analysis and mapping.
\end{abstract}

Keywords: mountain permafrost, classification algorithms, machine learning, mapping

\section{Introduction}

Within the $21^{\text {st }}$ century the Alpine environment is going to experience deep modifications of the cryosphere as a consequence of the increase in air temperatures and the modifications of precipitation regimes. Among the cryospheric components, mountain permafrost describes a ground with temperatures at or below $0^{\circ} \mathrm{C}$ for two consecutive years (Harris et al., 2009; Beniston et al., 2017). Permafrost in rock walls and sedimentary accumulations may degrade as a consequence of the climate change (Etzelmüller and Frauenfelder, 2009). A thickening of the active layer and a warming of the permafrost body can have various effects on mountain slope stabilities, such as an increasing rock fall activity (Gruber and Haeberli, 2007; Ravanel et al., 2010) or a rock glacier acceleration (Kääb et al., 2007; Roer et al., 
2008; Delaloye et al., 2010; PERMOS, 2016), leading to an increase of the sediment transfer rates (Lane et al., 2007; Kobierska et al., 2011).

In the European Alps, the periglacial belt is generally marked by the absence of trees, a reduced vegetation cover (where existing essentially made of meadow, mosses and lichens), large volumes of sediment debris, steep slopes and rock faces. Althought permafrost may affect all these different types of terrains, its unambiguous morphological manifestation only occurs in active rock glaciers, which are considered as the visible expression of mountain permafrost creep (Haeberli, 1985). Other permafrost indicators are thrust- or push-moraines, corresponding to frozen sediments deformed by the glacier advance during the Little Ice Age, whereas large areas in glacier forefields located in the periglacial belt appear to be unfrozen (Reynard et al., 2003; Harris and Murton, 2005; Kneisel and Kääb, 2007; Bosson et al., 2015). Talus slopes constitute other major landforms of alpine environments where permafrost is generally restricted to the lower half of the slope (e.g. Lambiel and Pieracci, 2008; Otto and Sass, 2006; Scapozza et al., 2011). It is also well established that terrains covered by alpine meadow are generally permafrost free (Haeberli, 1975). The distribution of mountain permafrost is thus extremely discontinuous in mountain areas (see also Ribolini et al., 2010; Otto et al., 2012).

The ability of modelling the spatial distribution of such a complex phenomenon became an important task for the alpine permafrost research during the last two decades. First empirico-statistical models were based on simple approaches (such as linear regression) and offered a good overview of the potential distribution of mountain permafrost at the regional scale (i.e. Hoelzle, 1994; Ebohon and Schrott, 2008; Avian and Kellerer-Pirklbauer, 2012). These models are generally thresholding the occurrence of permafrost on the basis of a restricted number of topographical and climatic parameters (i.e. altitude of rock glacier fronts for a given orientation) and are validated with measurements of the ground surface temperature, which may be subject to bias. The availability of an increasing amount of high resolution data (generally derived from high resolution digital elevation models) opened then the way to new complex statistical models able to deal with a large number of predictors (i.e. Boeckli et al., 2012; Schöner et al., 2012; Magnin et al., 2015; Azócar et al., 2016; Sattler et al., 2016). Although they offer a good overview of the permafrost distribution at local scale (i.e. scale of a valley side), these models do not reflect the great heterogeneity of the phenomenon at the scale of a specific landform (the micro scale; covering ten to several hundreds of meters).

To address the need of an improved prediction of the permafrost extent at the micro scale, we propose an alternative approach, which employs classification algorithms belonging to statistics and machine learning, namely Logistic regression, Support Vector Machines and Random forests. These algorithms can deal with complex and high dimensional datasets (Bishop, 2006) and they derive functional dependencies directly from data without appealing to physical models (Hastie et al., 2009). They have successfully been adopted for mapping the spatial distribution of several natural phenomena (i.e. Amatulli et al., 2013; Varley et al., 2016). In the periglacial research such techniques have been already used for geomorphological mapping (Luoto and Hjort, 2005), landform characterization (Marmion et al., 2008) or permafrost mapping using satellite images (Ou et al., 2016). Accordingly, we collected field observations indicating the known presence or the known absence of mountain permafrost and related topo-climatic data 
for a specific area of the Western Swiss Alps. The dataset built was analyzed and used to investigate the potential of machine learning techniques for mapping the high spatial discontinuity of mountain permafrost. Furthermore, as the potential permafrost distribution in rockwalls had already been successfully modeled in other studies (i.e. Gruber et al., 2004; Noetzli et al., 2007; Magnin et al., 2015), the present work focuses only on sedimentary accumulations.

\section{Materials and methods}

\subsection{Permafrost evidences and explanatory variables}

This study was carried out in a sector of the Western Valais Alps (Switzerland) covering a regular grid of $588 \mathrm{~km}^{2}$, with more than $60 \%$ above the theoretical permafrost lower limit of 2500 m.a.s.l., delimiting the lower boundary of the periglacial belt in the area (Lambiel and Reynard, 2001).

We used evidences of known permafrost presence or absence collected since the mid 1990s by the Universities of Lausanne and Fribourg as training data for employed machine learning algorithms (figure 1). These evidences have been obtained from two distinct sources:

- Rock glacier inventories. Permafrost presence or absence can be derived from rock glacier maps, based on their activity. Indeed, active or inactive rock glaciers suggest the existence of permafrost conditions, whereas relict ones indicate its absence (see Haeberli, 1985; Humlum, 1996; Barsch, 2012). For this study, we employed some existing inventories (Delaloye and Morand, 1998; Morand, 2000; Lambiel and Reynard, 2003), for which rock glaciers were mapped directly in the field. Some additional rock glaciers located within the study area were also added through ortho-image interpretation. All rock glacier limits were then corrected with a comparison with recent orthophotos (Swissimage, from swisstopo) and their activity was verified with the analysis of geomorphic signatures and InSAR signals (Delaloye et al., 2007; Barboux et al., 2014).

- Geoelectrical and thermal data. Direct-current (DC) resistivity methods are well established tools for detecting permafrost in sediments (Hauck and Kneisel, 2008). Electrical resistivity tomography (ERT) is especially often utilized to detect ground ice and characterize frozen materials in permafrost environments (e.g. Hauck et al., 2003; Hilbich et al., 2009; Otto et al., 2012). In addition, permafrost can also be inferred from ground surface temperature measurements (Hoelzle et al., 1999; Carturan et al., 2015). Coupling geoelectrical and thermal data can thus improve the reliability of permafrost mapping. Following the procedure employed by Lambiel (2006, p. 95) and Scapozza et al. (2011), we compiled and combined geoelectrical and thermal data collected in the framework of different studies aiming at detecting and mapping ground ice in permafrost environments mainly talus slopes and glacier forefields - of our study area (Marescot et al., 2003; Reynard et al., 2003; Delaloye, 2004; Delaloye and Lambiel, 2005; Lambiel, 2006; Delaloye and Lambiel, 2008; Lambiel and Pieracci, 2008; Scapozza et al., 2011; Scapozza, 2013; Staub et al., 2015). Completed by thermal measurements gathered for the Swiss Permafrost Monitoring Network (PERMOS, 2016) and by other unpublished projects, these 
data were used to map the permafrost extension in the prospected landforms. This provided to the classification algorithms additional training examples also located outside rock glaciers. Negative training observations (known permafrost absence) resulted not only from in-situ measurements indicating warm conditions or absence of ground ice, but also from expert knowledge. We particularly used the conclusions of Lambiel and Pieracci (2008) and Scapozza et al. (2011) that showed the general absence of permafrost in the upper half of talus slopes.

For this study, we selected environmental variables that are commonly used in the field of permafrost modelling (e.g. Etzelmüller et al., 2001; Guglielmin et al., 2003; Boeckli et al., 2012) such as altitude, mean annual air temperature, aspect, terrain slope angle and potential incoming solar radiation. In addition, we computed the NDVI and the planar, profile and combined terrain curvature indices, which are morphometric predictors important in characterizing specific periglacial landforms such as rock glaciers or moraines. The relevance of selected predictions is presented in the following sub-sections:

- Altitude: Permafrost occurrence increases with the altitude at the regional scale, due to the decrease of the mean annual air temperature (MAAT) at higher altitudes. As MAAT is calculated on the basis on a linear temperature gradient $\left(-0.59^{\circ} \mathrm{C} / 100 \mathrm{~m}\right.$ above $1500 \mathrm{~m}$, for methodology see Bouët, 1978), these two predictors were extremely correlated (see figure 2). Accordingly, to avoid redundancy, the adopted dataset excluded the MAAT variable and only considered the altitude. The latter is derived from the SwissAlti3D digital elevation model from the Swiss Federal Office of Topography (swisstopo). It is a spatial grid with an aperture width of $2 \mathrm{~m}$ above $2000 \mathrm{~m}$.a.s.l. and it is produced by stereo correlation with $1-3 \mathrm{~m}$ average error. The density of at least 2 points $/ \mathrm{m}^{2}$ avoids noise in the data.

- Aspect: The terrain orientation is also considered extremely relevant for the permafrost presence / absence. Terrains with different aspects have different energy inputs due to a different radiation angle. The amount of energy per unit area can actually vary in a ratio of 1 to 10 between the sunny side and the shady side of a relief. Since terrain orientation is a circular variable (between $0^{\circ}$ and $360^{\circ}$ ), we built two uncorrelated indicators: the "northness", which corresponds to the cosine of aspect angle, and the "eastness", equal to the minus sine of the aspect value (see Brenning and Trombotto, 2006).

- Slope: The terrain slope angle influences the permafrost occurrence by governing the direct solar radiation reaching the ground surface. In addition, snow cover may have different depths depending on the slope: rock walls are generally snow free while flat areas of footslopes may be covered by an important amount of snow (Mittaz et al., 2002).

- Potential incoming solar radiation: The amount of energy reaching the ground was calculated as potential incoming solar radiation (PSIR). For this we used the ArcMap "Area Solar Radiation" tool on the $2 \mathrm{~m}$ DEM, taking into account shadowing effect of the relief. PSIR was computed for the snow free period, between the 
July $1^{\text {st }}$ and October $31^{\text {th }}$ (which usually corresponds to the period without snow cover), because PSIR does not have relevant effects on the ground temperature if the snow is present (Hoelzle, 1994).

- Terrain curvature: As mountain permafrost is a thermal phenomenon, it is only observable with the appearance of geomorphological indices such as rock glaciers lobes or with in-situ measurements. Thus, adding a curvature indicator helps recognizing the presences of lobes that are potentially occupied by permafrost. The Gaussian terrain curvature (the derivative of the slope angle) was computed at different window sizes (10, 30, 50, 100, $500,1000 \mathrm{~m}$ ) and was included to the dataset as an indicator of various landforms. Large window curvatures (i.e. concavities) help machine learning algorithms to detect the presence of a valley bottom. Conversely, small window terrain curvatures indicate lobes, crests or small depressions (figure 3).

- Normalized Difference Vegetation Index: A Normalized Difference Vegetation Index (NDVI) was also calculated from false-color infrared images (swisstopo) and included in the dataset. This continuous variable is used for differentiating the vegetation from other land types, as well as characterize local variability in sediment textures.

\subsection{Adopted dataset}

A delimited area in which proposed simulations were run (the so-called validity domain) was defined based on categorical variables. The prediction of the permafrost occurrence was only computed for sectors where the latter is uncertain (the prediction can be either "permafrost absence" or "permafrost presence"), typically in sedimentary accumulations such as talus slopes, moraine deposits or other debris surfaces. Areas were permafrost is generally absent, such as temperate glaciers, rivers, lakes or vegetation areas, were excluded from the validity domain (table 1).

The dataset was built on a regular grid of $10 \times 10 \mathrm{~m}$. Consequently, the original DEM raster and relative extracted predictors controlling the presence and absence of mountain permafrost were resampled by computing the mean value of the $2 \times 2 \mathrm{~m}$ cells. A spatial resolution of $10 \mathrm{~m}$ was selected in reason of the computational requirements needed to predict the permafrost distribution for such an extended study area and the minimum size of typical periglacial landforms, such as rock glacier or moraine ridges, that can be represented with at least 2 pixels (a width of $20 \mathrm{~m}$ ). A higher resolution of the dataset would introduce unexpected noise, both in the attributes (i.e. erroneous attribute values) and the class (label noise, i.e. contradictory examples or missclassifications). This would require additional preprocessing and noise filtering analysis to reduce the noise's effects. Moreover, due to the complexity of the studied phenomenon, from a physical perspective willing to map the permafrost distribution at a too high resolution is illusory.

\subsection{Training, validation and test sets}

In the present research, classification algorithms were trained, validated and tested with separate independent subsets obtained from the original permafrost dataset. The latter can be considered a benchmark data bank to be used for the analysis of the influence of environmental predictors on the permafrost distribution as well as for the modelling of 
the potential permafrost distribution with machine learning (both are parts of ongoing research). These sub-sets were selected by sampling individual observations from group of data with different characteristics, previously identified by clustering the original input space (the variable space) with the help of a Self-Organizing Map (SOM, Kohonen, 1982; Kohonen and Honkela, 2007). This type of artificial neural network was trained using unsupervised learning and provided an ordered mapping of the data observations onto a two-dimensional grid. The SOM algorithm computed different models associated with each node of the grid. Observations were mapped into the node whose model is similar to data observation itself. The 2-dimensional map was then clusterized by using the k-means algorithm, while the number of clusters was selected by computing the Davies-Bouldin index (Davies and Bouldin, 1979). By grouping observations with similar characteristics within the input space, a balanced selection from pools of samples with similar characteristics was made. Rather than randomly sampling the permafrost observations, this sampling strategy avoided the presence of highly auto-correlated training samples within the separate sub-sets and produced less classification overfitting.

\subsection{Classifiers}

In this work, three classifiers were applied to permafrost data. At present, a large palette of classification methods, belonging to statistics and machine learning, exists (Kanevski et al., 2009). For instance, some of these common statistical techniques are the k-nearest neighbor (e.g. Altman, 1992; Everitt et al., 2011), the linear discriminant analysis (e.g. Friedman, 1989) and the logistic regression (see McLachlan, 2004). More recently, other complex algorithms have been developed in order to deal with the emergence of complex set of data and the lack of nonlinear solutions. Artificial neural networks, Support Vector Machines and Random forests are just a few examples (Cherkassky and Mulier, 2007; Izenman, 2008; Haykin, 2009; Hastie et al., 2009). These algorithms aim at assigning the class of an observation (here a pixel of the study grid) based on related environmental variables. In order to work, these techniques require a set of training data that are used to fit the classification decision function.

In the following sections, a theoretical overview of Logistic regression (LR), Support Vector Machines (SVM) and Random forests (RF) is given. We selected these algorithms because they belong to three specific sub-domain of machine learning: the former is a linear parametric classifier and it is commonly used as a benchmark classifier to be employed before using more complex classification algorithms. Non-linear SVM is a non-parametric learning algorithm and it is a member of the so-called kernel methods. Finally, RF are an ensemble learning method based on bootstrap aggregating.

\subsubsection{Logistic regression}

Logistic regression is one of the most used method for susceptibility mapping in geosciences (see Brenning, 2005; Trigila et al., 2015). This technique fits the best model between independent indicators to dependent variables (Kleinbaum and Klein, 1994). In our case, it tries to estimate the best mathematical relationship between the absence and the presence of permafrost and a set of explanatory independent environmental variables $x_{1}, \ldots, x_{n}$, which can be 
both continuous or categorical (Hosmer and Lemeshow, 2000). The model output for each grid cell represents the probability $p$ to belong to the permafrost presence. It is based on the logistic function $p_{i}$, which is defined as follows:

$$
\operatorname{logit}\left(p_{i}\right)=\log \left[\frac{p_{i}}{1-p_{i}}\right]
$$

where the likelihood ratio corresponds to the ratio between the probability $p$ that the predicted class is 1 (presence of permafrost) and the probability $1-p$ that the class is 0 (absence of permafrost). The final linear logistic model takes this form:

$$
\operatorname{logit}\left(p_{i}\right)=\beta_{0}+\sum_{i=1}^{n} \beta_{i} x_{i}
$$

with $\beta_{0}, \beta_{1}, \ldots, \beta_{n}$ the coefficients measuring how each independent environmental variable contributes to the permafrost occurrence.

In the present work, the logistic regression is performed using its implementation in WEKA, which is an improved version of the original algorithm presented in Le Cessie and Van Houwelingen (1994).

\subsubsection{Support Vector Machines}

Support Vector Machines (SVM) is a machine learning algorithm based on the statistical learning theory developed by Vapnik (1998). It is based on Structural Risk Minimization that minimizes the training error and controls the complexity of the model in order to improve the generalization ability of a model (Cherkassky and Mulier, 2007).

SVM can be applied to classification tasks and non-linear regression problems. The main principle of this technique presupposes that the set of training vectors $D=\left\{\left(x_{1}, y_{1}\right),\left(x_{2}, y_{2}\right), \ldots,\left(x_{n}, y_{n}\right)\right\}$ where $x_{i} \in R^{m}, i=1, \ldots, n$ with two classes $y_{i}=\{-1,1\}$ is linearly separable by a hyper-plane:

$$
(w \cdot x)+b=0, w \in R^{N}, b \in R
$$

where $w$ corresponds to the hyper-plane normal, $(\cdot)$ is a scalar product and $b$ is a scalar base.

The SVM algorithm aims at maximizing the largest margin that separates the training vectors and that is expressed as $\frac{2}{\|w\|}$ after the normalization. The maximum margin is computed as follows:

$$
\min _{w, b} \frac{1}{2}\|w\|^{2}
$$

subjecting to the constrains $y_{i}\left(w^{T} x_{i}+b\right) \geq 1, i=1,2, \ldots, n$.

The cost function is expressed as:

$$
\emptyset(w, b ; \alpha)=\frac{1}{2}\|w\|^{2}-\sum_{i=1}^{n} \alpha_{i}\left(y_{i}\left[w \cdot x_{1}+b\right]-1\right)
$$

where $\alpha=\left(\alpha_{1}, \alpha_{2}, \ldots, \alpha_{n}\right)^{T} \in R_{+}^{n}$ is a Lagrangian multiplier.

As detailed in Vapnik (1998), the problem has to be solved by dual minimization of the cost function with the respect to $w$ and $b$. Because in most cases the training vectors are rarely linearly separable, a slack variable $\xi_{i}$ and a 
penalty term $C$, avoiding high values of the latter, are introduced:

$$
y_{i}\left(\left(w \cdot x_{i}\right)+b\right) \geq 1-\xi_{i}, i=1,2, \ldots, n, \xi_{i} \geq 0
$$

Therefore, the equation, maximizing the margin becomes:

$$
\min \frac{1}{2}\|w\|^{2}+C \sum_{i=1}^{n} \xi_{i}
$$

Non-linear classification of real data is performed using the same principles, but only by applying a kernel trick (Vapnik, 1998) when a kernel function $K\left(x_{i}, x_{j}\right)$ maps/transforms the original data into a high dimensional feature space where, again, we are looking for a linear solution. Depending on the kernel, the linear solution in the feature space corresponds to a non-linear solution in the original space and the kernel controls the complexity of this mapping.

In this work, we used a radial basis function (RBF) kernel $K\left(x_{i}, x_{j}\right)=e^{\left(-\gamma\left\|x_{i}-x_{j}\right\|^{2}\right)}, \gamma>0$ which is one of the most used kernels providing a good generalization. Moreover, we employed the libSVM library implemented in WEKA. For additional information on the application of this algorithm, please see Deluigi and Lambiel (2012).

\subsubsection{Random forests}

Developed by Breiman (2001), Random Forests is an ensemble algorithm that computes $n$ binary classification trees (forest) with the purpose of having higher predictive capabilities compared to the classification with a single decision tree (Cutler et al., 2007). With the combination of several trees constructed with a random selection of the inputs, the classification accuracy usually improves. Implemented in WEKA, this technique is suitable when dealing with both categorical and numerical predictors. It adopts bagging to randomly select permafrost observations and their relative variables to train the model. The membership of a class is selected by a majority vote for the most popular class within the total number of trees. In this study, we used by default $2 / 3$ bootstrap of the training set to construct each tree. The remaining $1 / 3$ bootstrap of the training data was used to assess the generalization capacity of the algorithm.

With this technique there is thus no need for a cross-validation or a separate validation set to obtain unbiased estimate of the test set error. Unselected observations serve indeed to calculate the error of the model (the "out-of-bag" error, or $\mathrm{OOB}$ ). The error estimate also allows measuring the contribution of each predictor by computing the average decrease in model accuracy on the OOB samples when the values of the respective feature are randomly permuted. Two evaluators of the variable importance exist with Random forests: the Mean-Decrease-in-Accuracy, measuring the decrease of the accuracy expressed with the OOB-error when a variable is left out and the Mean-Decrease-in-Gini index, defining how the output at each node is impure (Breiman, 2001).

Because of the random selection of independent variables and observations at each node, it is suggested analysing the correct number of trees to be employed in Random forests in order to obtain a stable model (Catani et al., 2013). Therefore, before applying the classification model on a new prediction, we firstly investigated the changes in the OOB error curve, aiming at selecting the correct number of trees (see section 3.1). 


\subsection{Classification quality measures}

The known permafrost absence and presence was binary coded as [-1, 1]. Nevertheless, with the chosen classifiers it is possible to obtain the probability of belonging to the class as model output. This result is in fact most convenient when dealing with a natural phenomenon.

The quality of the prediction of the presence and absence of permafrost modeled with supervised learning algorithms can be generally assessed with multiple statistics (Doswell III et al., 1990). As we deal with binary classification, in this study we computed 2-by-2 contingency tables that display four possible cases (see figure 4): number of true positives (TP), i.e. a pixel with known permafrost presence that was predicted correctly (presence-presence); true negatives (TN), when absence is correctly not encountered (absence-absence); false negatives (FN), i.e. permafrost presence is not detected (presence-absence) or false positives (FP) for permafrost absence incorrectly forecasted (absence-presence). Indeed, when dealing with the management of natural hazards related to periglacial source areas, it is preferable to obtain a conservative result that miss-classifies permafrost where in reality it is not, rather than the opposite.

In addition to these rates, a Receiver Operating Characteristics curve (ROC) can be built (Fawcett, 2006). This 2-dimensional graph measures the quality of the model prediction by plotting the FP rate as the horizontal axis and the TP rate as the vertical axis, according to different susceptibility threshold values. Swets (1988) indicates that the Area Under the ROC curve (or AUROC) ranges between 0.5 and to 1 . Values between 0.5 and 0.7 generally indicate that the learned model has poor predictive capabilities. When AUROC is between 0.7 and 0.8 , it means that the classification have moderate predictive abilities. Between 0.8 and 0.9 they are considered good and above 0.9 they become excellent. Nevertheless, recent studies have observed that, for similar AUROCs, the predicted map of a given phenomenon can be particularly different (i.e. Micheletti et al., 2014).

\subsection{Used softwares}

In this research we have used algorithms that are already implemented in WEKA (Waikato University, Hall et al., 2009). The LibSVM library (Chang and Lin, 2011) is implemented in this software as a package. Permafrost evidence identification, variables extraction and dataset building were performed by using ArcGIS (ESRI) and Matlab softwares.

\section{Results and discussion}

In order to select the best map of the potential distribution of mountain permafrost for the Western part of the Valais Alps, modelling performances of standard Logistic regression were compared to the ones of Support Vector Machines and Random forests. The model setup was characterized by the selection of training and test data including observations of the permafrost presence and permafrost absence coupled together with environmental variable grids. As mentioned, we decided to present the algorithm predictions in the form of probabilities, which provide easiness 
when comparing different model outputs. Moreover, for coherence with existing models and ease of map comparability, presented maps visualize probabilities greater than 0.5 , corresponding to the possible presence of permafrost.

\subsection{Model assessment}

By removing auto-correlated variables from the dataset (figure 2) before applying the Logistic regression, the algorithm converged to a solution, providing an AUROC value of 0.807 (table 2). The sum of percentage of false positives and false negatives is greater than $25 \%$ of the total prediction. Besides, $11.5 \%$ of the study area is simulated as potentially frozen (726’397 pixel of the prediction grid with $p>0.5)$.

The prediction of the permafrost occurrence with RF was performed with the same sub-set used for LR. The variability of the $\mathrm{OOB}$ error was analyzed in order to select the correct number of trees to use. As figure 6 illustrates, the out-of-bag error becomes stable between 200 and 250 trees. We decided thus to use 300 trees for the RF modelling configuration.

Obtained classification AUROC is 0.884 and around $20 \%$ of the total number of observations correspond to false positives and false negatives. A total of 793'117 pixel was predicted with a positive occurrence of permafrost, that is $12.6 \%$ of the area of interest. The extent of the permafrost presence $(p>0.5)$ is thus slightly greater than the one obtained with Logistic regression. The number of expected false positives also decreases with this algorithm. Compared to the map of the permafrost distribution produced with LR, RF map is less smooth, with the presence of some spatial artefacts, which is a common issue encountered when using this technique (Brenning, 2005). However, it is worth mentioning that permafrost lower limits are visually located at the same altitude to the ones obtained with LR (see figures 5.A and 5.B).

A RBF kernel was selected as a kernel function for the non-linear SVM classification, accordingly to results obtained in a preliminary test study of Deluigi and Lambiel (2012). After the cross-validation step, the kernel parameters, as well as the regularization parameter $C$ and the threshold $\xi$, were optimized via grid search. The number of support vectors is close to the $39 \%$ of the training observations (around $36^{\prime} 000$ samples). This value is not only dependent on how much slack is allowed, but also on the complexity of the model. To allow users interpreting the binary result provided by SVM in a meaningful way, the classification of presence and absence of permafrost was transformed by post-processing to yield a posteriori probability (from categorical to probabilistic prediction). The technique, presented by Platt (1999), applies a maximum likelihood-optimized logistic transformation on the SVM decision function in order to obtain permafrost probabilities. Classification AUROC of the RBF-SVM is equal to 0.848 , with around $14.2 \%$ of the total prediction classified as false positives and false negatives. The number of pixels indicating a probability of permafrost occurrence greater than 0.5 is $11^{\prime} 079^{\prime} 745$, which corresponds to $17.13 \%$ of the total region extent. This is reflected by a map with more extensive surface potentially occupied by permafrost. 


\subsection{Model comparison}

It is common practice in machine learning to estimate the classification error by using cross-validation and to choose the algorithm that provides the lowest estimate. However, it is important to investigate which model is statistically the best when performing a specific classification task. ROC curves (figure 7) were evaluated on independent test sets for comparing the generalization performances of LR, SVM and RF.

Resulting performances were compared by using the Model Evaluator module of WEKA (see Witten and Frank, 2005) that employs a paired t-test (confidence: 0.05, two tailed) (table 3). Results of the test indicate that SVM is not significantly worse than RF. However, the paired t-test outcome suggests that RF is significantly better than LR.

\subsection{Expert domain quality evaluation}

In addition to the statistical evaluation of the presented models, the three maps were also analysed according to their geomorphological relevance. The lower limit of permafrost given by SVM is $100-150 \mathrm{~m}$ lower than the one given by LR and RF, being more in accordance with field observations (see figures 8.A, 8.B and 8.C). SVM probabilities appear to be generally higher than the ones given by LR and RF. In comparison with the permafrost map of the Swiss Federal Office for the Environment (BAFU, 2005) or the Alpine Permafrost Index Map (APIM) of Boeckli et al. (2012), the proposed simulations provide less optimistic results. Indeed, especially for LR and RF, the prediction of the presence of permafrost in sediments is restricted to smaller surfaces. In addition, maps produced by using machine learning do not present the typical altitude thresholds that indicate higher permafrost occurrence with the increase in altitude (see Lambiel and Reynard, 2001; BAFU, 2005; Schrott et al., 2012; Boeckli et al., 2012). As the relationship between permafrost evidences and environmental predictors is learnt directly from data without recurring to physical models, probabilities are predicted for each independent pixel. Machine learning algorithms appear thus more suitable to simulate the high spatial discontinuity of the phenomenon at the micro scale.

Despite the conservative result in terms of surfaces potentially frozen and a slightly lower AUROC compared to RF, SVM granted a classification with the lowest number of miss-classifications. Obtained AUROCs range mid-way between existing studies such as Boeckli et al. (2012), Azócar et al. (2016) and Sattler et al. (2016). This may be explained by the addition to the adopted dataset of indicators of know permafrost absence not only restricted to relict rock glacier, but also in talus slopes and other sediment accumulations.

When observing the interpretability of the proposed maps, the RF map is less smooth than the LR and SVM ones and presents a higher number of artefacts. Conversely, SVM gives less variability of probability when observing a given pixel and the one in the neighborhood. Furthermore, the potential distribution of permafrost is more conservative with this approach. Its great heterogeneity is also better respected with SVM. In fact, LR produces probabilities higher than 0.5 that increase linearly with the altitude. If the permafrost probability increases effectively with the altitude at the regional scale, permafrost occurrence at the local scale can change within distances of few tens of meters due to the high variability of the local characteristics (see Otto et al., 2012; Rödder and Kneisel, 2012). In some talus slopes, the SVM map illustrates a lower probability in the mid-upper part of the slope (figure 8.C). As showed by 
Lambiel and Pieracci (2008) or Scapozza et al. (2011) this distribution is more in accordance with the field reality. The same behaviour is also partially simulated with LR and RF, but their result is less conservative and it presents an increased number of false positives and false negatives. In glacier forefields, highlighted with a yellow mask in figure 5.D), the permafrost distribution may be even more complex due to thermal and mechanical perturbations by the glacier advance during the Little Ice Age (Reynard et al., 2003; Kneisel and Kääb, 2007). These studies illustrated that permafrost is often restricted to the lateral and frontal margin of these environments, where the former glacier was the thinnest. Hence, one has to be careful when looking at the potential permafrost extent within these areas.

\section{Conclusions}

In this study we presented the results of the classification and mapping of mountain permafrost data using Logistic regression (LR), Random forests (RF) and Support Vector Machines (SVM) in a large area of the Western Swiss Alps. Machine learning algorithms provided precise distribution maps at the micro scale by learning the statistical relationship between training permafrost evidences and permafrost explanatory variables. LR predicted a smooth map with an increase of the permafrost probability linearly with the altitude, which does not reflect the strong spatial discontinuity of the phenomenon. RF provided excellent classification performances despite the similar permafrost extent of the LR map, but it differs in terms of the result smoothness. SVM model performance resides between the two other applied classifiers. It is characterized by a lower number of miss-classifications and the potential permafrost map obtained tends to be more conservative in comparison to LR and RF. In addition, the permafrost discontinuity was best reproduced with SVM. Conversely to LR, the occurrence of permafrost does not tend to increase linearly with the altitude and it is indeed possible to observe higher permafrost probabilities in the lower half of some talus slopes, which is in agreement with field data.

The internal mechanisms of the three employed classification algorithms open the way to further analysis on permafrost data such as active learning, allowing choosing training data from selected support vectors, and featuring ranking, with embedded measures of the variable importance. It follows that the approach presented not only helps in mapping the mountain permafrost distribution but can also be employed to understand related data properties. Much research remains thus to be done to improve the prediction at the micro scale. For example, model uncertainties characterization could reduce misclassification of known permafrost evidences and thus improve the model robustness. The extraction of new environmental variables controlling permafrost conditions at the micro scale, such as the grain size of sedimentary deposits, could as well help refining obtained results.

\section{Acknowledgements}

We thank two anonymous reviewers for their constructive comments. We would also like to acknowledge the Swiss National Science Foundation for the funding of this research (project no. 200021_152924) as well as Prof. R. 
Delaloye and colleagues from the University of Fribourg for having provided permafrost evidences.

\section{References}

Altman, N. S. (1992). An introduction to kernel and nearest-neighbor nonparametric regression. The American Statistician, 46(3):175-185.

Amatulli, G., Camia, A., and San-Miguel-Ayanz, J. (2013). Estimating future burned areas under changing climate in the EU-Mediterranean countries. Science of the Total Environment, 450:209-222.

Avian, M. and Kellerer-Pirklbauer, A. (2012). Modelling of potential permafrost distribution during the Younger Dryas, the Little Ice Age and at present in the Reisseck Mountains, Hohe Tauern Range, Austria. Austrian Journal of Earth Sciences, 105(2):140-153.

Azócar, G. F., Brenning, A., and Bodin, X. (2016). Permafrost Distribution Modeling in the Semi-Arid Chilean Andes. The Cryosphere Discussions, 2016:1-25.

BAFU (2005). Hinweiskarte der potenziellen Permafrostverbreitung der Schweiz. Bundesamt für Umwelt.

Barboux, C., Delaloye, R., and Lambiel, C. (2014). Inventorying slope movements in an Alpine environment using DInSAR. Earth Surface Processes and Landforms, 39(15):2087-2099.

Barsch, D. (2012). Rockglaciers: indicators for the present and former geoecology in high mountain environments, volume 16. Springer Science \& Business Media.

Beniston, M., Farinotti, D., Stoffel, M., Andreassen, L. M., Coppola, E., Eckert, N., Fantini, A., Giacona, F., Hauck, C., Huss, M., Huwald, H., Lehning, M., López-Moreno, J.-I., Magnusson, J., Marty, C., Moran-Tejéda, E., Morin, S., Naaim, M., Provenzale, A., Rabatel, A., Six, D., Stötter, J., Strasser, U., Terzago, S., and Vincent, C. (2017). The European mountain cryosphere: A review of past, current and future issues. The Cryosphere Discussions, 2017:1-60.

Bishop, C. M. (2006). Pattern recognition. Machine Learning, 128.

Boeckli, L., Brenning, A., Gruber, S., and Noetzli, J. (2012). A statistical approach to modelling permafrost distribution in the European Alps or similar mountain ranges. The Cryosphere, 6(1):125-140.

Bosson, J.-B., Deline, P., Bodin, X., Schoeneich, P., Baron, L., Gardent, M., and Lambiel, C. (2015). The influence of ground ice distribution on geomorphic dynamics since the Little Ice Age in proglacial areas of two cirque glacier systems. Earth Surface Processes and Landforms, 40(5):666-680.

Bouët, M. (1978). Le Valais. Klimatologie der Schweiz 2. Régionale Beschreibungen. 1. Teil. Beih. Ann. Schweiz. Meteorolog. Zentralanst, 1977:88-114.

Breiman, L. (2001). Random forests. Machine learning, 45(1):5-32.

Brenning, A. (2005). Spatial prediction models for landslide hazards: review, comparison and evaluation. Natural Hazards and Earth System Science, 5(6):853-862.

Brenning, A. and Trombotto, D. (2006). Logistic regression modeling of rock glacier and glacier distribution: topographic and climatic controls in the semi-arid Andes. Geomorphology, 81(1):141-154.

Carturan, L., Zuecco, G., Seppi, R., Zanoner, T., Borga, M., Carton, A., and Dalla Fontana, G. (2015). Catchment-Scale Permafrost Mapping using Spring Water Characteristics. Permafrost and Periglacial Processes, 27(3):253-270.

Catani, F., Lagomarsino, D., Segoni, S., and Tofani, V. (2013). Landslide susceptibility estimation by random forests technique: sensitivity and scaling issues. Natural Hazards and Earth System Sciences, 13(11):2815-2831.

Chang, C.-C. and Lin, C.-J. (2011). LIBSVM: a library for support vector machines. ACM Transactions on Intelligent Systems and Technology (TIST), 2(3):27.

Cherkassky, V. and Mulier, F. (2007). Learning from data: concepts, theory, and methods. John Wiley \& Sons.

Cutler, D. R., Edwards, T. C., Beard, K. H., Cutler, A., Hess, K. T., Gibson, J., and Lawler, J. J. (2007). Random forests for classification in ecology. Ecology, 88(11):2783-2792.

Davies, D. L. and Bouldin, D. W. (1979). A cluster separation measure. IEEE transactions on pattern analysis and machine intelligence 2, pages 224-227. 
Delaloye, R. (2004). Contribution à l'étude du pergélisol de montagne en zone marginale. PhD thesis, Université de Fribourg.

Delaloye, R. and Lambiel, C. (2005). Evidence of winter ascending air circulation throughout talus slopes and rock glaciers situated in the lower belt of alpine discontinuous permafrost (Swiss Alps). Norsk Geografisk Tidsskrift, 59(2):194-203.

Delaloye, R. and Lambiel, C. (2008). Typology of vertical electrical soundings for permafrost/ground ice investigation in the forefields of small alpine glaciers. In Hauck, C. and C, K., editors, Applied Geophysics in Periglacial Environments, chapter 8, pages 101-108. Cambridge University Press.

Delaloye, R., Lambiel, C., and Gärtner-Roer, I. (2010). Overview of rock glacier kinematics research in the Swiss Alps: seasonal rhythm, interannual variations and trends over several decades. Geographica Helvetica, 65(2):135-145.

Delaloye, R., Lambiel, C., Lugon, R., Raetzo, H., and Strozzi, T. (2007). Typical ERS InSAR signature of slope movements in a periglacial mountain environment (Swiss Alps). In Proceedings Envisat Symposium, volume ESA SP-636, Montreux, Switzerland.

Delaloye, R. and Morand, S. (1998). Les glaciers rocheux de la région d'Entremont (Alpes valaisannes): inventaire et analyse spatiale à l'aide d'un SIG. In Mitteilungen der Versuchsantalt für Wasserbau, Hydrologie und Glaziologie, volume 158, pages 75-86. ETH Zürich.

Deluigi, N. and Lambiel, C. (2012). PERMAL: a machine learning approach for alpine permafrost distribution modeling. In Graf, C., editor, Mattertal - ein Tal in Bewegung. Jahrestagung der Schweizerischen Geomorphologischen Gesellschaft, volume 4, pages 47-62.

Doswell III, C. A., Davies-Jones, R., and Keller, D. L. (1990). On summary measures of skill in rare event forecasting based on contingency tables. Weather and Forecasting, 5(4):576-585.

Ebohon, B. and Schrott, L. (2008). Modeling Mountain Permafrost Distribution: A New Permafrost Map of Austria. In Kane, D. and Hinkel, K., editors, Proceedings of the Ninth International Conference on Permafrost, pages 397-402, Fairbanks, Alaska.

Etzelmüller, B. and Frauenfelder, R. (2009). Factors controlling the distribution of mountain permafrost in the Northern Hemisphere and their influence on sediment transfer. Arctic, Antarctic, and Alpine Research, 41(1):48-58.

Etzelmüller, B., Hoelzle, M., Flo Heggem, E. S., Isaksen, K., Mittaz, C., Mühll, D. V., Ødegård, R. S., Haeberli, W., and Sollid, J. L. (2001). Mapping and modelling the occurrence and distribution of mountain permafrost. Norsk Geografisk Tidsskrift-Norwegian Journal of Geography, 55(4):186-194.

Everitt, B. S., Landau, S., Leese, M., and Stahl, D. (2011). Miscellaneous clustering methods. Cluster Analysis, 5th Edition, pages $215-255$.

Fawcett, T. (2006). An introduction to ROC analysis. Pattern recognition letters, 27(8):861-874.

Friedman, J. H. (1989). Regularized discriminant analysis. Journal of the American statistical association, 84(405):165-175.

Gruber, S. and Haeberli, W. (2007). Permafrost in steep bedrock slopes and its temperature-related destabilization following climate change. Journal of Geophysical Research: Earth Surface (2003-2012), 112(F2).

Gruber, S., Hoelzle, M., and Haeberli, W. (2004). Rock-wall temperatures in the Alps: modelling their topographic distribution and regional differences. Permafrost and Periglacial Processes, 15(3):299-307.

Guglielmin, M., Aldighieri, B., and Testa, B. (2003). PERMACLIM: a model for the distribution of mountain permafrost, based on climatic observations. Geomorphology, 51(4):245-257.

Haeberli, W. (1975). Untersuchungen zur Verbreitung von Permafrost zwischen Flüelapass und Piz Grialetsch (Graubünden). Versuchsanstalt für Wasserbau, Hydrologie und Glaziologie.

Haeberli, W. (1985). Creep of mountain permafrost: internal structure and flow of alpine rock glaciers. Mitteilungen der Versuchsanstalt fur Wasserbau, Hydrologie und Glaziologie an der ETH Zurich, 77:5-142.

Hall, M., Frank, E., Holmes, G., Pfahringer, B., Reutemann, P., and Witten, I. H. (2009). The WEKA data mining software: an update. ACM SIGKDD explorations newsletter, 11(1):10-18.

Harris, C., Arenson, L., Christiansen, H. H., Etzelmuller, B., Frauenfelder, R., Gruber, S., Haeberli, W., Hauck, C., Hoelzle, M., Humlum, O., Isaksen, K., Kääb, A., Kern-Luetschg, M., Lehning, M., Matsuoka, N., Murton, J. B., Noezli, J., Phillips, M., Ross, N., Seppala, M., Springman, S. M., and D., V. M. (2009). Permafrost and climate in Europe: Monitoring and modelling thermal, geomorphological and geotechnical responses. Earth-Science Reviews, 92(3):117-171.

Harris, C. and Murton, J. (2005). Interactions between glaciers and permafrost: An introduction. Geological Society Special Publication, 242:1-9. 
Hastie, T., Tibshirani, R., and Friedman, J. (2009). Unsupervised learning. In The elements of statistical learning, pages 485-585. Springer.

Hauck, C. and Kneisel, C. (2008). Electrical methods. Applied geophysics in periglacial environments, pages 3-27.

Hauck, C., Vonder Mühll, D., and Maurer, H. (2003). Using DC resistivity tomography to detect and characterize mountain permafrost. Geophysical prospecting, 51(4):273-284.

Haykin, S. (2009). Neural networks and learning machines, volume 3. Pearson Education Upper Saddle River.

Hilbich, C., Marescot, L., Hauck, C., Loke, M., and Mäusbacher, R. (2009). Applicability of electrical resistivity tomography monitoring to coarse blocky and ice-rich permafrost landforms. Permafrost and Periglacial Processes, 20(3):269-284.

Hoelzle, M. (1994). Permafrost und Gletscher im Oberengadin: Grundlagen und Anwendungsbeispiele für automatisierte Schätzverfahren. Mitteilungen der Versuchsanstalt für Wasserbau, Hydrologie und Glaziologie an der Eidgenössischen Technischen Hochschule Zürich. VAW.

Hoelzle, M., Wegmann, M., and Krummenacher, B. (1999). Miniature temperature dataloggers for mapping and monitoring of permafrost in high mountain areas: first experience from the Swiss Alps. Permafrost and periglacial processes, 10(2):113-124.

Hosmer, D. W. and Lemeshow, S. (2000). Introduction to the logistic regression model. Applied Logistic Regression, Second Edition, pages 1-30.

Humlum, O. (1996). Origin of rock glaciers: observations from Mellemfjord, Disko Island, central West Greenland. Permafrost and Periglacial Processes, 7(4):361-380.

Izenman, A. (2008). Modern multivariate statistical techniques: regression. Classification, and Manifold Learning Springer Texts in Statistics, New York.

Kääb, A., Frauenfelder, R., and Roer, I. (2007). On the response of rockglacier creep to surface temperature increase. Global and Planetary Change, 56(1):172-187.

Kanevski, M., Pozdnoukhov, A., and Timonin, V. (2009). Machine learning for spatial environmental data: theory, applications, and software. EPFL press.

Kleinbaum, D. and Klein, M. (1994). Logistic regression: a self-learning text Springer-Verlag. New York.

Kneisel, C. and Kääb, A. (2007). Mountain permafrost dynamics within a recently exposed glacier forefield inferred by a combined geomorphological, geophysical and photogrammetrical approach. Earth Surface Processes and Landforms, 32(12):1797-1810.

Kobierska, F., Jonas, T., Magnusson, J., Zappa, M., Bavay, M., Bosshard, T., Paul, F., and Bernasconi, S. (2011). Climate change effects on snow melt and discharge of a partly glacierized watershed in Central Switzerland (SoilTrec Critical Zone Observatory). Applied Geochemistry, 26:S60-S62.

Kohonen, T. (1982). Self-organized formation of topologically correct feature maps. Biological cybernetics, 43(1):59-69.

Kohonen, T. and Honkela, T. (2007). Kohonen network. Scholarpedia, 2(1):1568.

Lambiel, C. (2006). Le pergélisol dans les terrains sédimentaires à forte déclivité: distribution, régime thermique et instabilités. UNIL-Faculté des géosciences et de l'environnement-Institut de géographie.

Lambiel, C. and Pieracci, K. (2008). Permafrost distribution in talus slopes located within the alpine periglacial belt, Swiss Alps. Permafrost and Periglacial Processes, 19(3):293-304.

Lambiel, C. and Reynard, E. (2001). Regional modelling of present, past and future potential distribution of discontinuous permafrost based on a rock glacier inventory in the Bagnes-Hérémence area (Western Swiss Alps). Norsk Geografisk Tidsskrift-Norwegian Journal of Geography, 55(4):219-223.

Lambiel, C. and Reynard, E. (2003). Cartographie de la distribution du pergélisol et datation des glaciers rocheux dans la région du Mont Gelé (Valais). Physische Geographie, 41:91-104.

Lane, S., Tayefi, V., Reid, S., Yu, D., and Hardy, R. (2007). Interactions between sediment delivery, channel change, climate change and flood risk in a temperate upland environment. Earth Surface Processes and Landforms, 32(3):429-446.

Le Cessie, S. and Van Houwelingen, J. (1994). Logistic regression for correlated binary data. Applied Statistics, 43:95-108.

Luoto, M. and Hjort, J. (2005). Evaluation of current statistical approaches for predictive geomorphological mapping. Geomorphology, 67(3):299_ 315.

Magnin, F., Brenning, A., Bodin, X., Deline, P., and Ravanel, L. (2015). Statistical modelling of rock wall permafrost distribution: application to 
the Mont Blanc massif. Geomorphologie -Paris-, page 20.

Marescot, L., Loke, M., Chapellier, D., Delaloye, R., Lambiel, C., and Reynard, E. (2003). Assessing reliability of 2D resistivity imaging in mountain permafrost studies using the depth of investigation index method. Near Surface Geophysics, 1(2):57-67.

Marmion, M., Hjort, J., Thuiller, W., and Luoto, M. (2008). A comparison of predictive methods in modelling the distribution of periglacial landforms in Finnish Lapland. Earth Surface Processes and Landforms, 33(14):2241-2254.

McLachlan, G. (2004). Discriminant analysis and statistical pattern recognition, volume 544. John Wiley \& Sons.

Micheletti, N., Foresti, L., Robert, S., Leuenberger, M., Pedrazzini, A., Jaboyedoff, M., and Kanevski, M. (2014). Machine learning feature selection methods for landslide susceptibility mapping. Mathematical Geosciences, 46(1):33-57.

Mittaz, C., Imhof, M., Hoelzle, M., and Haeberli, W. (2002). Snowmelt Evolution Mapping Using an Energy Balance Approach over an Alpine Terrain. Arctic, Antarctic, and Alpine Research, 34(3):274-281.

Morand, S. (2000). Inventaire des glaciers rocheux du Val d'Arolla. Rapport interne, Service des forêts et du paysage du Canton du Valais, Sion.

Noetzli, J., Gruber, S., Kohl, T., Salzmann, N., and Haeberli, W. (2007). Three-dimensional distribution and evolution of permafrost temperatures in idealized high-mountain topography. Journal of Geophysical Research: Earth Surface (2003-2012), 112(F2).

Otto, J., Keuschnig, M., Goetz, J., Marbach, M., and Schrott, L. (2012). Detection of mountain permafrost by combining high resolution surface and subsurface information-an example from the Glatzbach catchment, Austrian Alps. Geografiska Annaler: Series A, Physical Geography, 94(1):43-57.

Otto, J. and Sass, O. (2006). Comparing geophysical methods for talus slope investigations in the Turtmann valley (Swiss Alps). Geomorphology, 76(3):257-272.

Ou, C., LaRocque, A., Leblon, B., Zhang, Y., Webster, K., and McLaughlin, J. (2016). Modelling and mapping permafrost at high spatial resolution using Landsat and Radarsat-2 images in Northern Ontario, Canada: Part 2-regional mapping. International Journal of Remote Sensing.

PERMOS (2016). Permafrost in Switzerland 2010/2011 to 2013/2014. Noetzli, J., Luethi, R., and Staub, B. (eds.). Glaciological Report (Permafrost) No. 12-15 of the Cryospheric Commission of the Swiss Academy of Sciences.

Platt, J. (1999). Probabilistic outputs for support vector machines and comparisons to regularized likelihood methods. Advances in large margin classifiers, 10(3):61-74.

Ravanel, L., Allignol, F., Deline, P., Gruber, S., and Ravello, M. (2010). Rock falls in the Mont Blanc Massif in 2007 and 2008. Landslides, 7(4):493-501.

Reynard, E., Lambiel, C., Delaloye, R., Devaud, G., Baron, L., Chapellier, D., Marescot, L., and Monnet, R. (2003). Glacier/permafrost relationships in forefields of small glaciers (Swiss Alps). In Proceedings 8th International Conference on Permafrost, Zurich, Switzerland, volume 2, pages 947-952.

Ribolini, A., Guglielmin, M., Fabre, D., Bodin, X., Marchisio, M., Sartini, S., Spagnolo, M., and Schoeneich, P. (2010). The internal structure of rock glaciers and recently deglaciated slopes as revealed by geoelectrical tomography: insights on permafrost and recent glacial evolution in the Central and Western Alps (Italy-France). Quaternary Science Reviews, 29(3):507-521.

Rödder, T. and Kneisel, C. (2012). Influence of snow cover and grain size on the ground thermal regime in the discontinuous permafrost zone, Swiss Alps. Geomorphology, 175:176-189.

Roer, I., Haeberli, W., Avian, M., Kaufmann, V., Delaloye, R., Lambiel, C., and Kääb, A. (2008). Observations and considerations on destabilizing active rock glaciers in the European Alps. In Ninth International Conference on Permafrost, volume 2, pages 1505-1510.

Sattler, K., Anderson, B., Mackintosh, A., Norton, K., and de Róiste, M. (2016). Estimating Permafrost Distribution in the Maritime Southern Alps, New Zealand, Based on Climatic Conditions at Rock Glacier Sites. Frontiers in Earth Science, 4:4.

Scapozza, C. (2013). Stratigraphie, morphodynamique, paléoenvironnements des terrains sédimentaires meubles à forte déclivité du domaine périglaciaire alpin. $\mathrm{PhD}$ thesis, Universit de Lausanne.

Scapozza, C., Lambiel, C., Baron, L., Marescot, L., and Reynard, E. (2011). Internal structure and permafrost distribution in two alpine periglacial talus slopes, Valais, Swiss Alps. Geomorphology, 132(3):208-221.

Schöner, W., Boeckli, L., Hausmann, H., Otto, J.-C., Reisenhofer, S., Riedl, C., and Seren, S. (2012). Spatial patterns of permafrost at Hoher 
Sonnblick (Austrian Alps)-extensive field-measurements and modelling approaches. Austrian Journal of Earth Sciences, 105(2):154-168.

Schrott, L., Otto, J.-C., and Keller, F. (2012). Modelling alpine permafrost distribution in the Hohe Tauern region, Austria. Austrian Journal of Earth Sciences, 105(2):169-183.

Staub, B., Marmy, A., Hauck, C., Hilbich, C., and Delaloye, R. (2015). Ground temperature variations in a talus slope influenced by permafrost: a comparison of field observations and model simulations. Geographica Helvetica, 70(1):45-62.

Swets, J. A. (1988). Measuring the accuracy of diagnostic systems. Science, 240(4857):1285-1293.

Trigila, A., Iadanza, C., Esposito, C., and Scarascia-Mugnozza, G. (2015). Comparison of Logistic Regression and Random Forests techniques for shallow landslide susceptibility assessment in Giampilieri (NE Sicily, Italy). Geomorphology, 249:119-136.

Vapnik, V. (1998). Statistical learning theory. Wiley, New York.

Varley, A., Tyler, A., Smith, L., Dale, P., and Davies, M. (2016). Mapping the spatial distribution and activity of 226 Ra at legacy sites through Machine Learning interpretation of gamma-ray spectrometry data. Science of the Total Environment, 545:654-661.

Witten, I. H. and Frank, E. (2005). Data Mining: Practical machine learning tools and techniques. Morgan Kaufmann. 


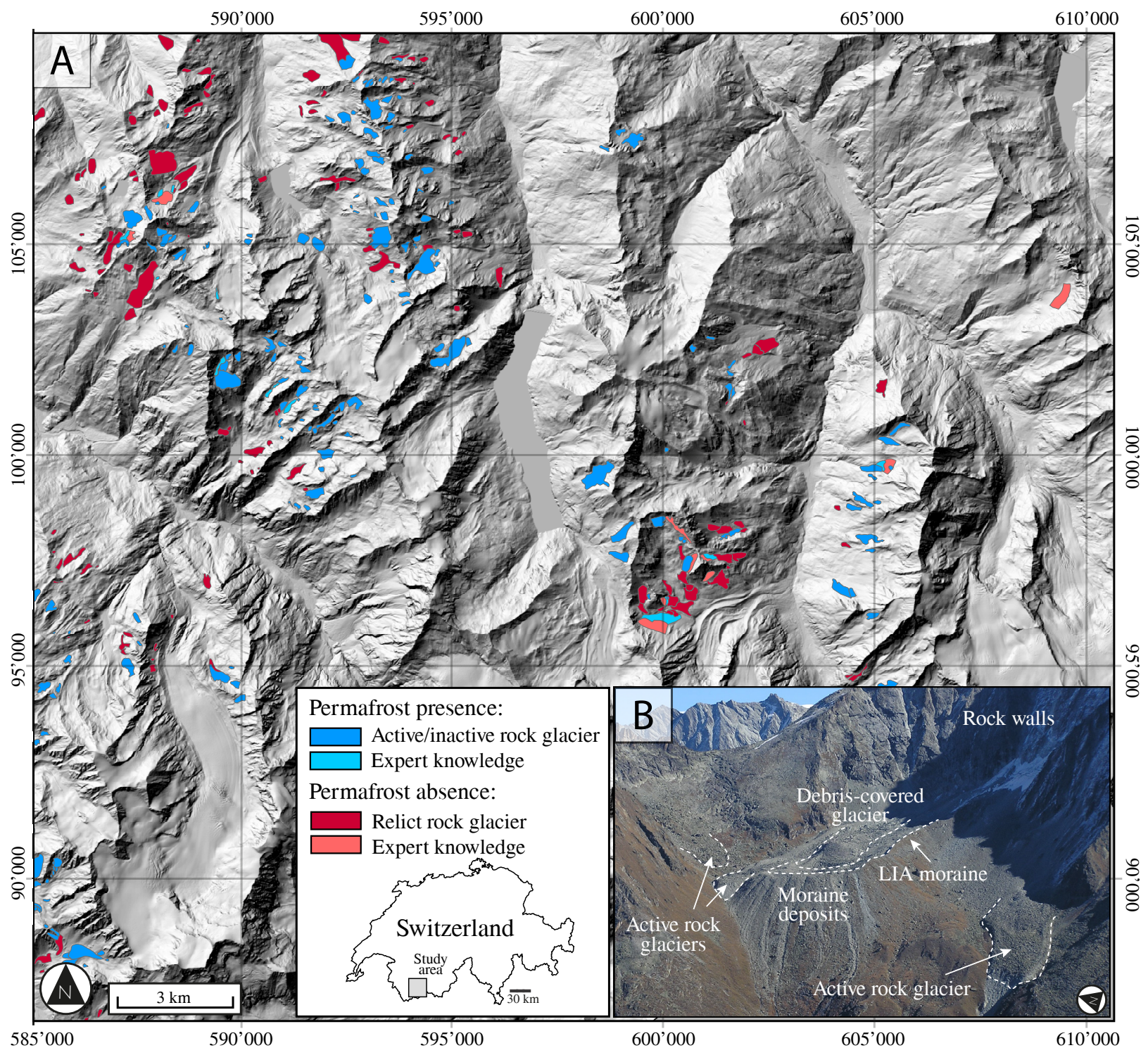

Figure 1: (A) Extent of the study area (relief map) and localization of known permafrost evidences. (B) Typical Alpine periglacial landscape characterized by active rock glaciers, debris-covered glacier, talus slopes, moraine deposits and rock walls (Arolla valley, Valais; photo: R. Delaloye). 


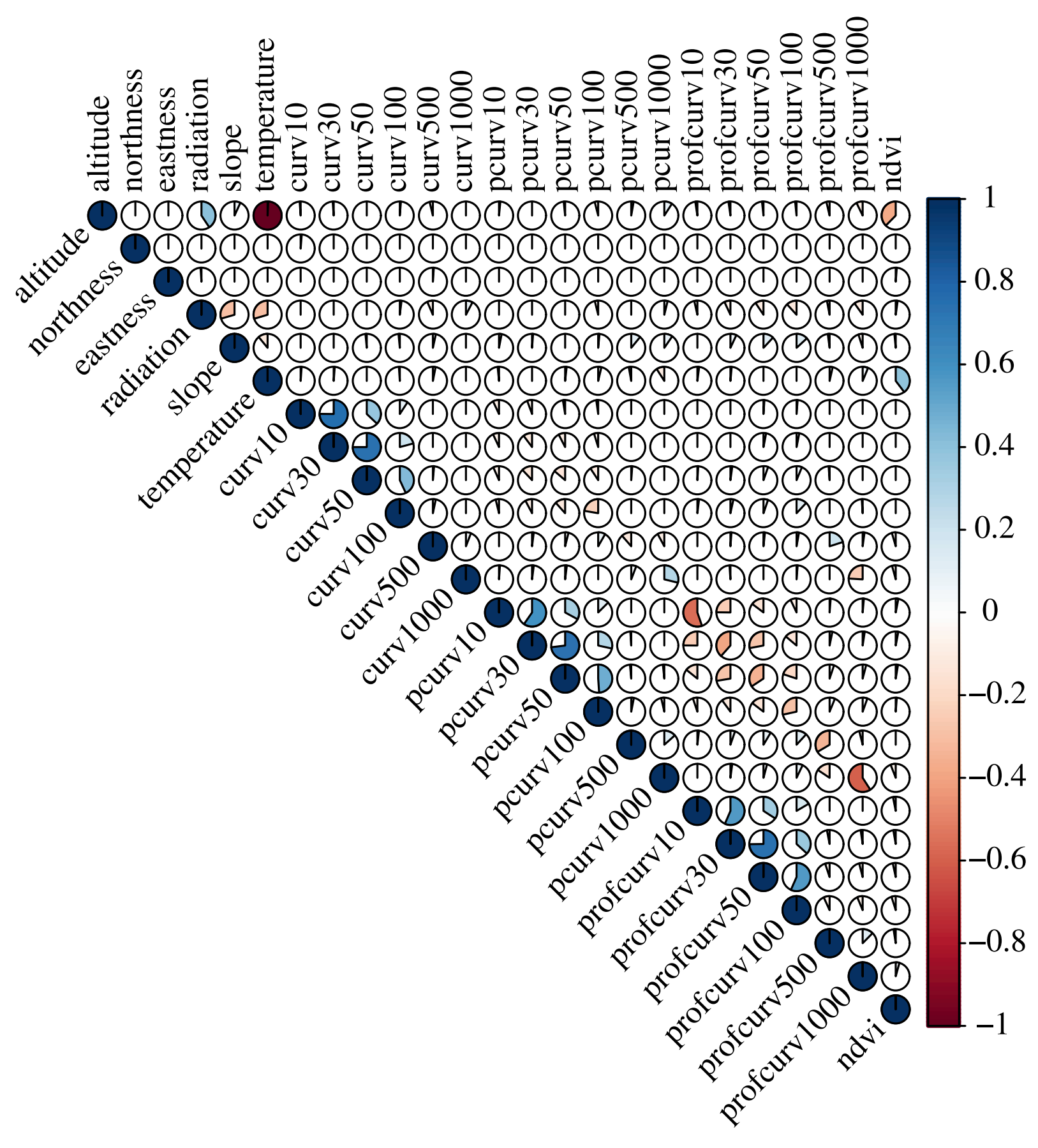

Figure 2: Correlation plot of selected environmental variables within the validity domain. 


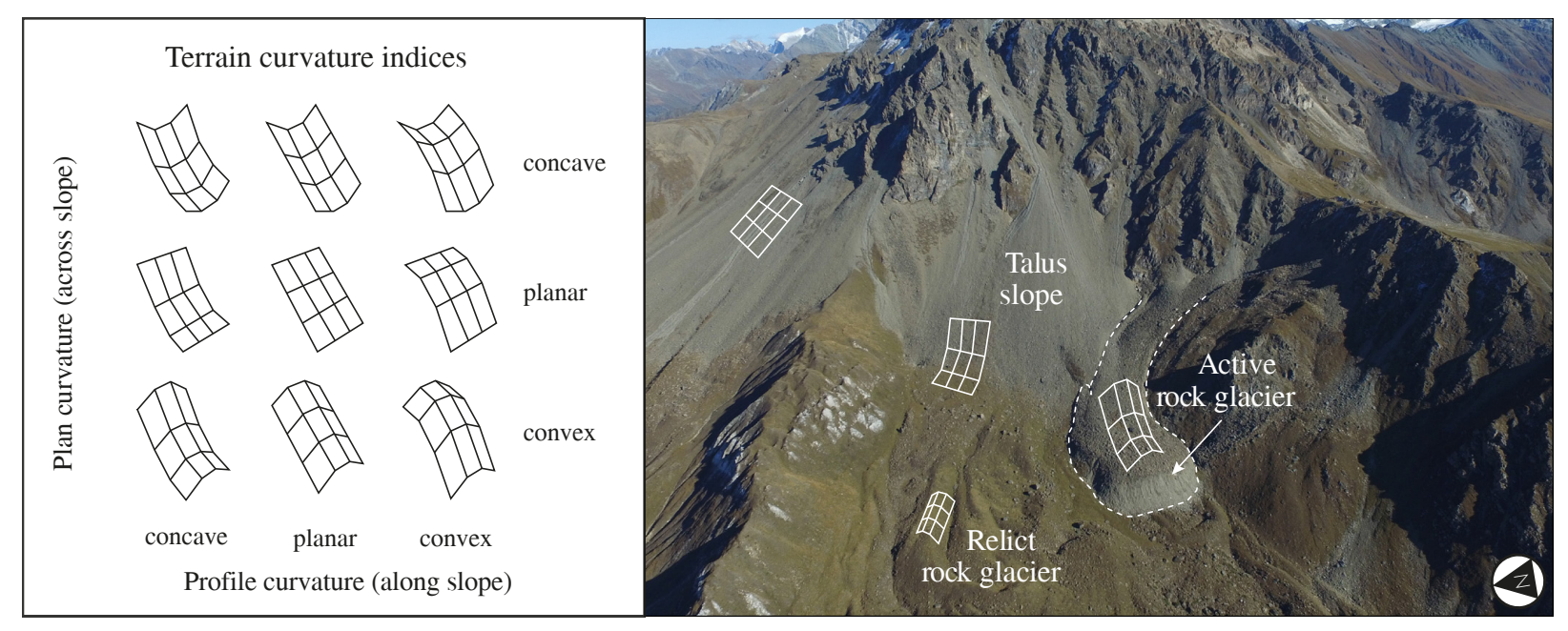

Figure 3: Terrain curvature types and associated landforms for Les Cliosses sector, with an active rock glacier indicating the presence of permafrost (Hérens Valley, Valais; photo: S. Rüttimann).

\begin{tabular}{c|c|c|}
\multicolumn{3}{c}{ Classification confusion matrix } \\
& $\begin{array}{c}\text { Predicted: } \\
\text { presence }\end{array}$ & $\begin{array}{c}\text { Predicted: } \\
\text { absence }\end{array}$ \\
\hline $\begin{array}{c}\text { Actual: } \\
\text { presence }\end{array}$ & $\begin{array}{c}\text { TRUE } \\
\text { POSITIVE }\end{array}$ & $\begin{array}{c}\text { FALSE } \\
\text { POSITIVE }\end{array}$ \\
\hline $\begin{array}{c}\text { Actual: } \\
\text { absence }\end{array}$ & FALSE & TRUE \\
\hline
\end{tabular}

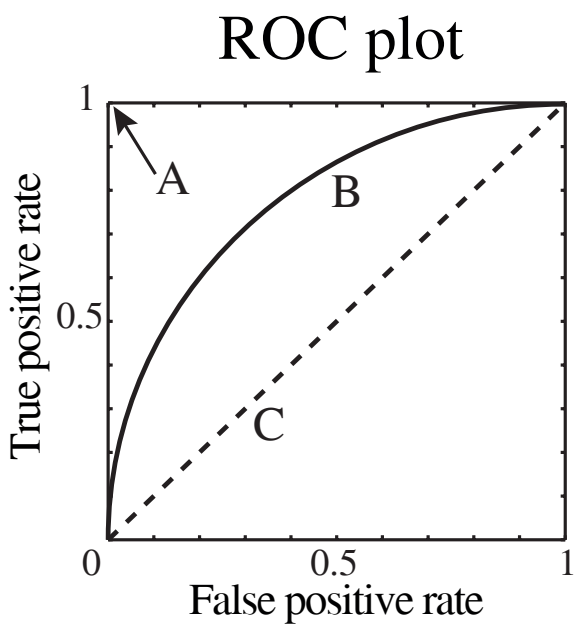

Sensivity $=\mathrm{TP} /(\mathrm{TP}+\mathrm{FN})$

Specificity $=\mathrm{TN} /(\mathrm{TN}+\mathrm{FP})$

False positive rate $(\mathrm{FPR})=1-$ Sensivity False negative rate $(F N R)=1$ - Specificity

Figure 4: Classification confusion matrix (left) and evaluation rates (bottom) used to assess the model quality. The Receiver Operating Characteristics curve also indicates the quality of the classification: $(\mathrm{A})$ corresponds to the perfect result (no errors, AUROC $=1$ ), (B) indicates a typical ROC curve $($ AUROC $=0.85)$ and $(\mathrm{C})$ refers to an inefficient classification $($ AUROC $=0.5$ ). 


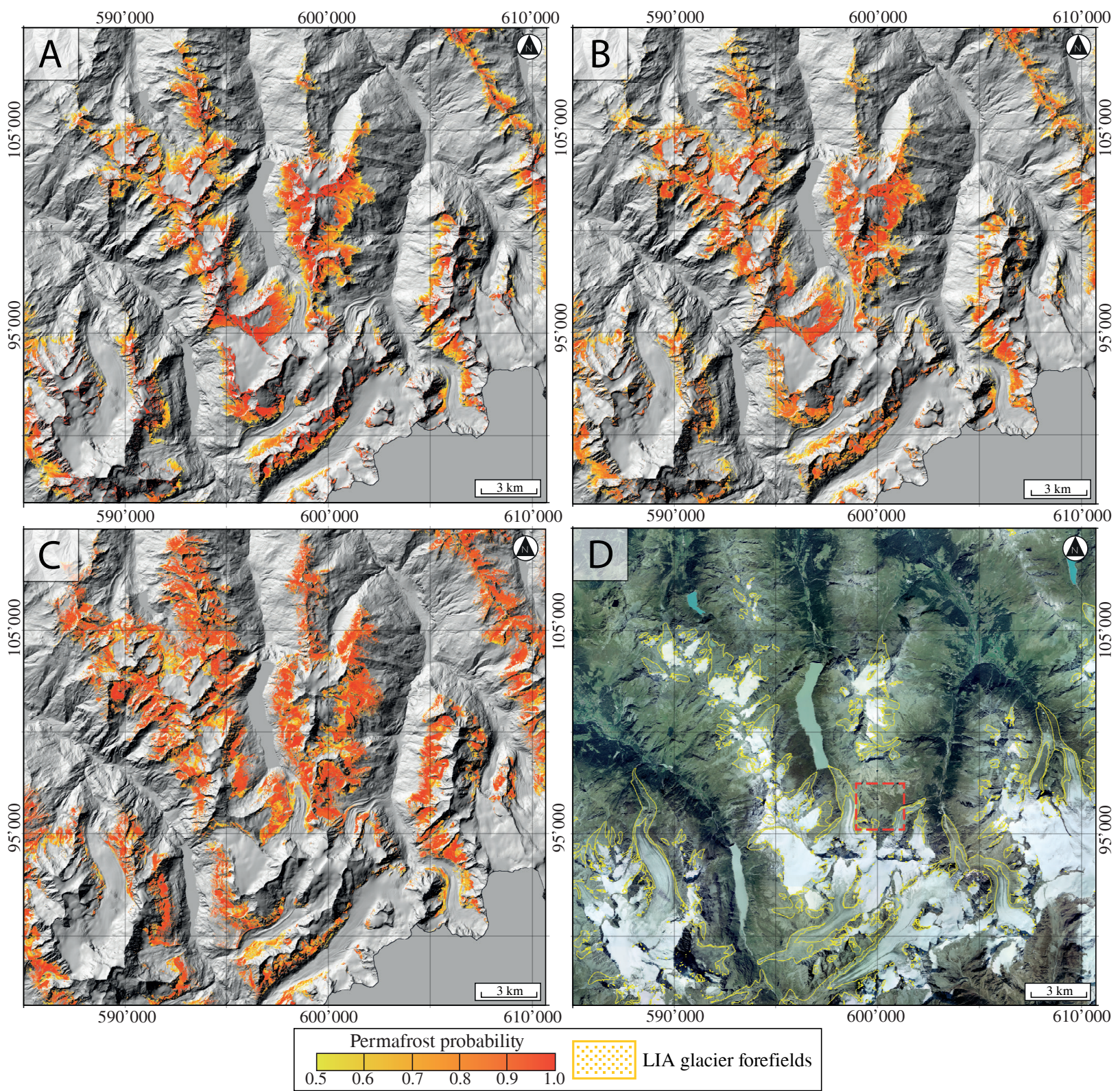

Figure 5: Permafrost distribution maps obtained with (A) Logistic regression, (B) Random Forests and (C) Support Vector Machines. (D) Groundtruth of the study area (aerial images from swisstopo) and LIA glacier forefield extent for ease of interpretation. Red dashed square indicates the location the overviews of the figure 8 . 


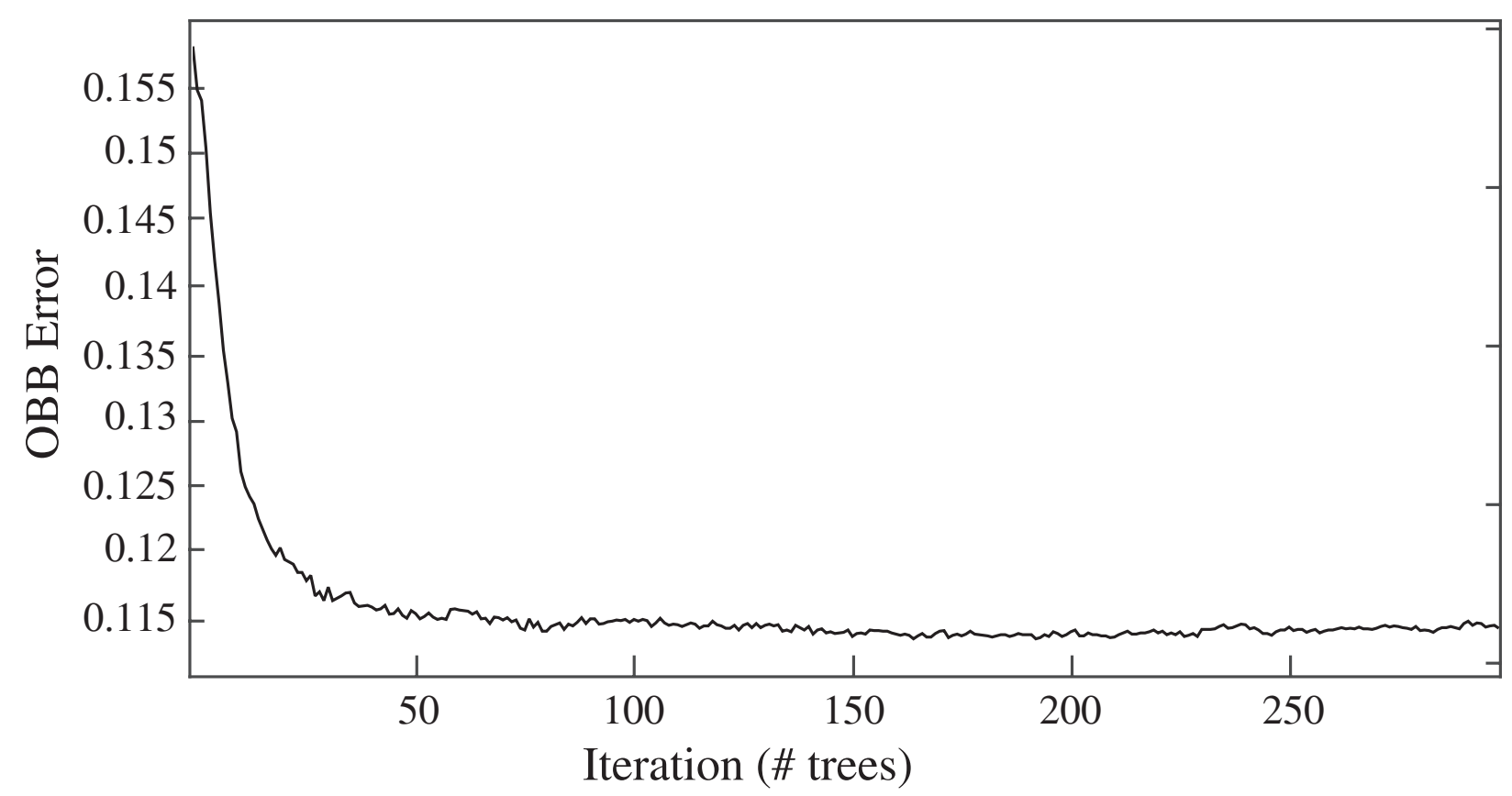

Figure 6: OBB error as a function of the number of trees.
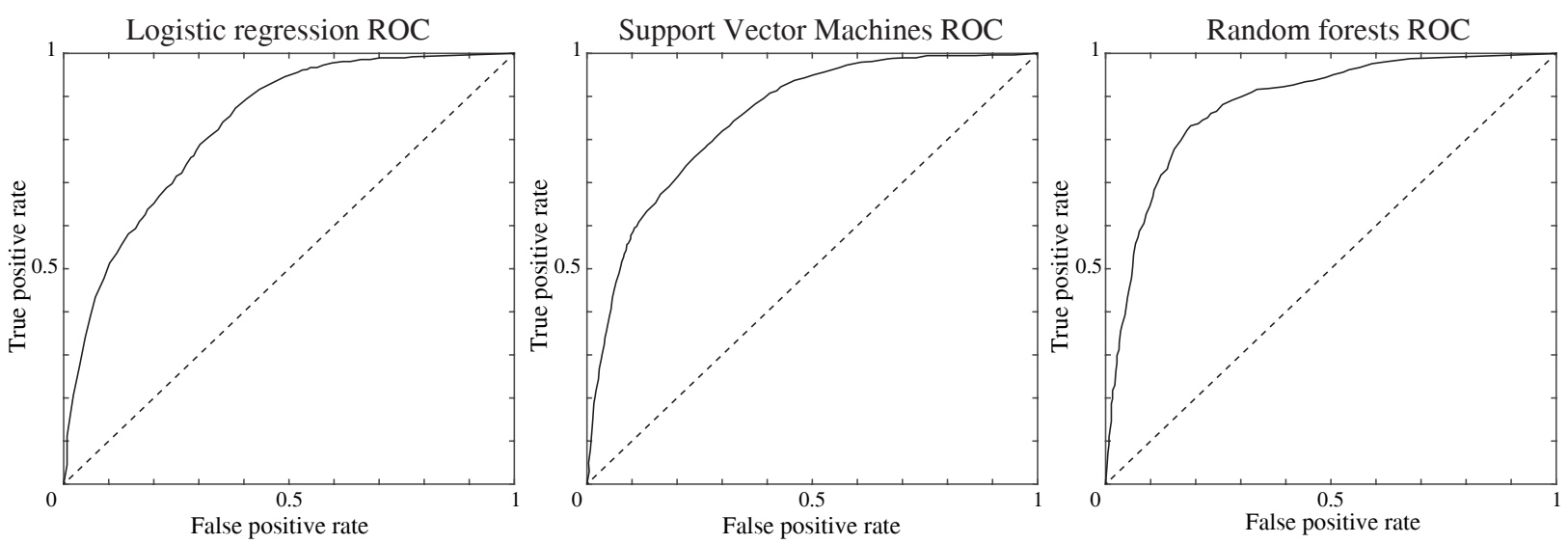

Figure 7: ROC curves for classification by Logistic regression (0.807, left), Support Vector Machines $(0.848$, center) and Random forests $(0.884$, right). 


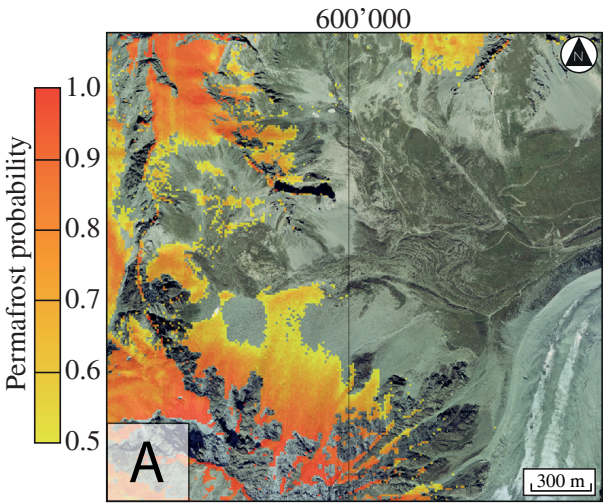

$600 ’ 000$

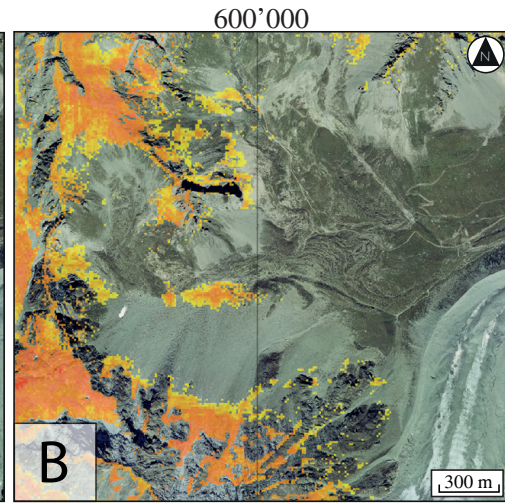

$600 ' 000$

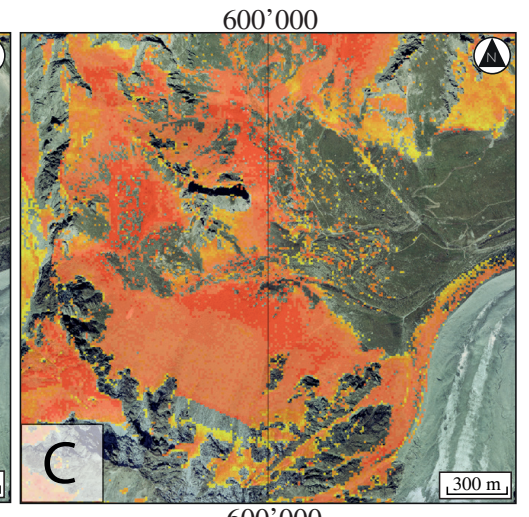

$600{ }^{\prime} 000$

Figure 8: Potential permafrost distribution in the Fontanesses sector (Arolla valley) obtained with (A) Logistic regression, (B) Random Forests and (C) Support Vector Machines.

\begin{tabular}{cll}
\hline \hline Variable name & Variable type & Use \\
\hline Altitude & Continuous & Classification \\
Northness & Continuous & Classification \\
Eastness & Continuous & Classification \\
Slope & Continuous & Classification \\
PSIR & Continuous & Classification \\
Air temperature & Continuous & Classification \\
Lake & Categorical & VD definition \\
Rockwall & Categorical & VD definition \\
River & Categorical & VD definition \\
NDVI & Continous & Classification / VD definition \\
Plan curvature $10 \mathrm{~m}$ & Continuous & Classification \\
Plan curvature $30 \mathrm{~m}$ & Continuous & Classification \\
Plan curvature $50 \mathrm{~m}$ & Continuous & Classification \\
Plan curvature $100 \mathrm{~m}$ & Continuous & Classification \\
Plan curvature $500 \mathrm{~m}$ & Continuous & Classification \\
Plan curvature $1000 \mathrm{~m}$ & Continuous & Classification \\
Profile curvature $10 \mathrm{~m}$ & Continuous & Classification \\
Profile curvature $30 \mathrm{~m}$ & Continuous & Classification \\
Profile curvature $50 \mathrm{~m}$ & Continuous & Classification \\
Profile curvature $100 \mathrm{~m}$ & Continuous & Classification \\
Profile curvature $500 \mathrm{~m}$ & Continuous & Classification \\
Profile curvature $1000 \mathrm{~m}$ & Continuous & Classification \\
Surface curvature $10 \mathrm{~m}$ & Continuous & Classification \\
Surface curvature $30 \mathrm{~m}$ & Continuous & Classification \\
Surface curvature $50 \mathrm{~m}$ & Continuous & Classification \\
Surface curvature $100 \mathrm{~m}$ & Continuous & Classification \\
Surface curvature $500 \mathrm{~m}$ & Continuous & Classification \\
Surface curvature $1000 \mathrm{~m}$ & Continuous & Classification \\
Glacier & Categorical & VD definition \\
\hline \hline & & \\
\hline
\end{tabular}

Table 1: Features contained in the raw dataset. Categorical variables serve constructing the validity domain (VD), continuous variables are used for classifying the permafrost occurrence. 


\begin{tabular}{cccc}
\hline Statistics & LR & SVM & RF \\
\hline Precision & 0.743 & 0.858 & 0.797 \\
Recall & 0.746 & 0.859 & 0.798 \\
AUROC & 0.807 & 0.848 & 0.884 \\
FP (\%) & 10.72 & 5.97 & 8.78 \\
FN (\%) & 14.70 & 8.17 & 11.37 \\
\# cells with $p>0.5$ & $726^{\prime} 397$ & 1'079'745 $^{\prime}$ & $793^{\prime} 117$ \\
\hline
\end{tabular}

Table 2: Summary statistics of the Logistic regression, Support Vector Machines and Random forests models.

\begin{tabular}{r|c|c|c} 
Classifier & SVM & RF & LR \\
\hline Performance (AUROC) & 0.848 & 0.884 & $0.807^{*}$ \\
& $\left(\mathrm{v} / /^{*}\right)$ & $(0 / 1 / 0)$ & $(0 / 0 / 1)$
\end{tabular}

Table 3: Model performances and paired t-test outcomes (v: significantly better, *: significantly worse). 


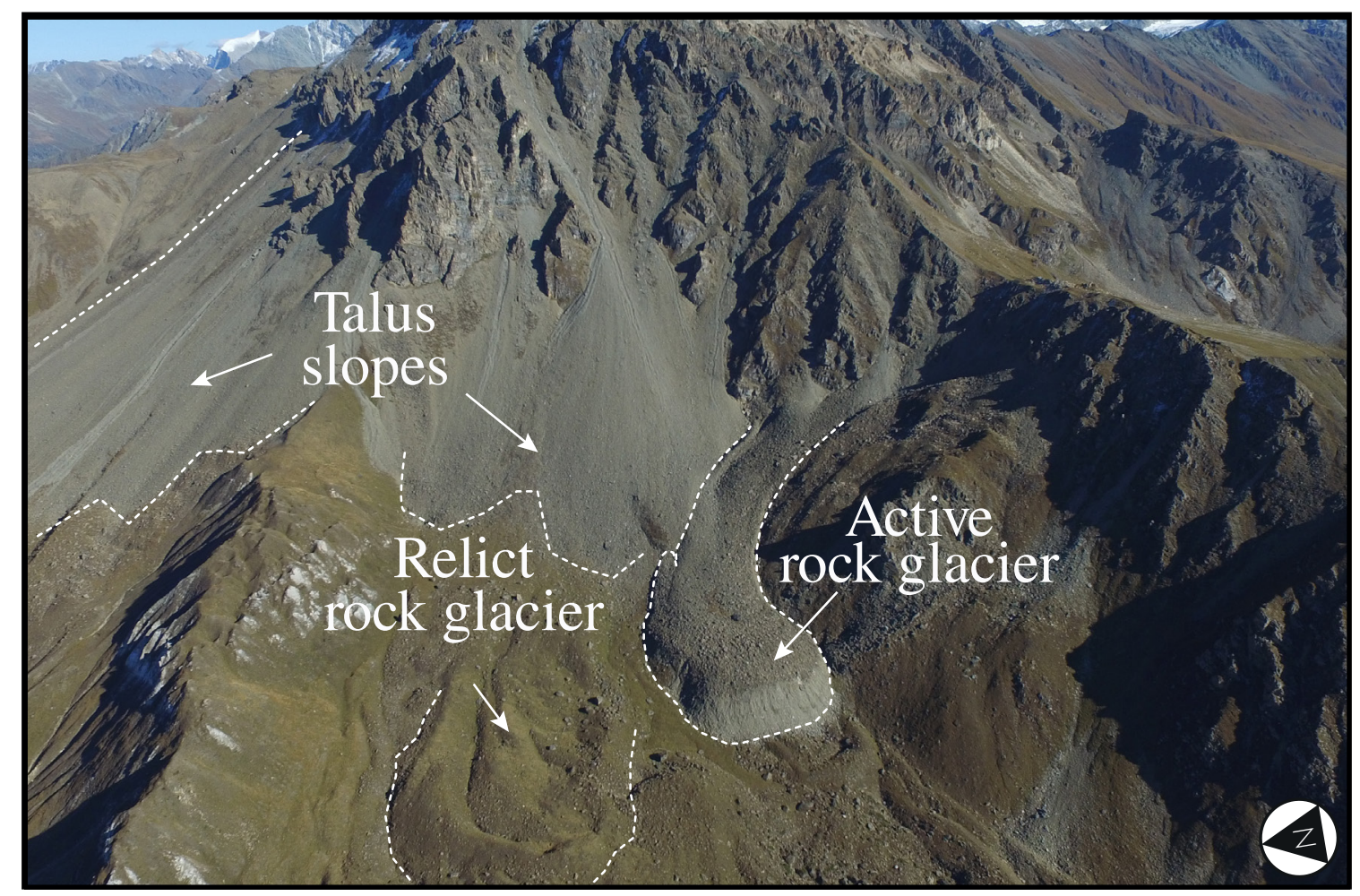

Dataset: positive/negative permafrost evidences and related permafrost predictors

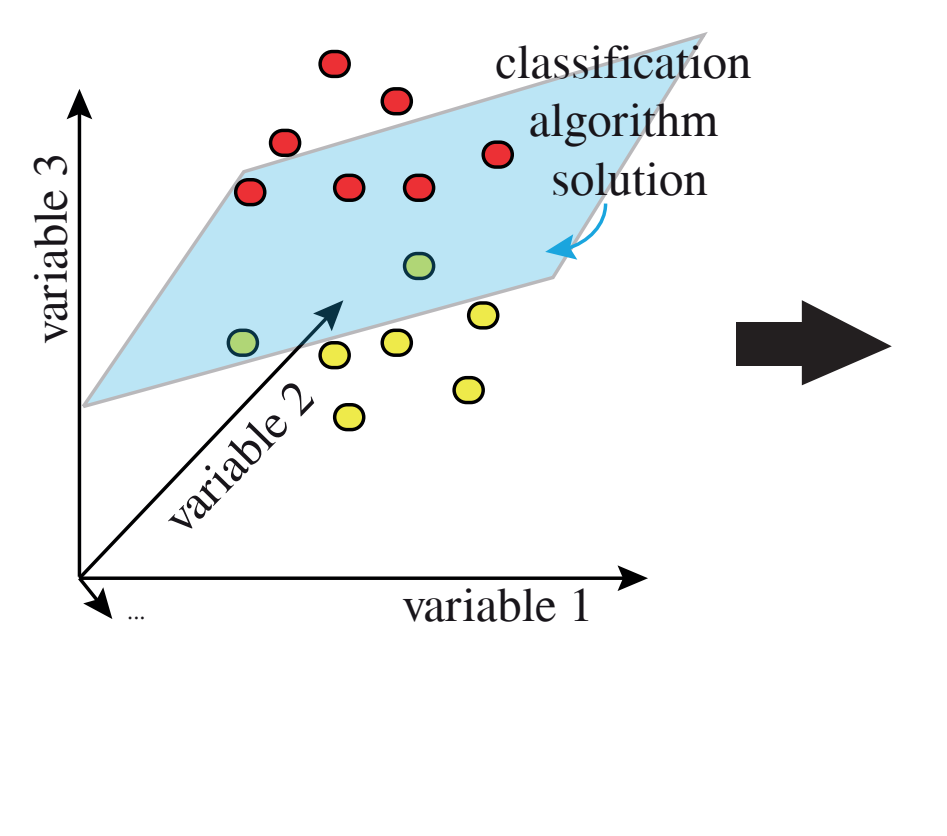

Machine learning classifier (learning from data)
Permafrost prediction 